Aleksandra Vranes
Ljiljana Markovic

University of Belgrade

Faculty of Philology
026/027:316.722

316.7

https://doi.org/10.18485/melissa.2017.16.1.ch2

\title{
TRANSCULTURALITY IN THE CONTEXT OF DIGITAL HUMANITIES ${ }^{1}$
}

\section{Summary}

The words of Ludwig Wittgenstein: "when we think of the world's future, we always mean the destination it will reach if it keeps going in the direction we can see it going in now; it does not occur to us that its path is not a straight line but a curve, constantly changing direction" are quite alive today, perhaps even more alive than when they were written. After the traditional concept of respect for and knowledge of individual cultures, the need for interculturality has developed within societies, followed by multiculturality, while most recently the idea of transculturality is propagated, which Wolfgang Welsch defined as "a consequence of the inner differentiation and complexity of modern cultures". Containing interpenetration of cultures and hybridization, transculturality gives a new quality to globalization, which has important support in the digital humanities.

Digital humanities represent a state-of-the-art link between our highly digital contemporary world and humanities, and deal with the challenges that the permeation of these two engender. The aim of this paper would be to consider digital humanities in relation to the notion of transculturality. We want to emphasize the fact that it is precisely through digital environment that various cultures are mixed and merged and that the understanding and interaction is achieved on a global level. We intend to determine the current place of transculturality within digital humanities, but also consider its possible future role in the framework of this modern discipline. We will base our research on the most significant documents in terms of digital humanities, such as the Digital Humanities Manifesto 2.0 by Schnapp and Presner, Epstein's manifesto The Transformative Humanities as well as the book Digital Humanities by Anne Burdick, Johanna Drucker, Peter Lunenfeld (et al.). This research will result in conclusions that will discern the current and future place of transculturality within digital humanities, but it will also offer an overview of the current state and possible future solutions for the digital presence and permeation of less-known cultures on the Internet. More broadly, the paper will explain

1 Paper was previously published: A. Vranes, L. Markovic (2017) Transculturality in the Context of Digital Humanities, INTED2017 Proceedings, pp. 9647-9653. 
how the idea of transculturality is confirmed, decomposed and build upon in the light of digital humanities.

Key words: transculturality, digital humanities, hybridization, Digital Humanities Manifesto 2.0, The Transformative Humanities, the book Digital Humanities.

\section{1 transculturality in the light of digital humanities}

The words of Ludwig Wittgenstein: "when we think of the world's future, we always mean the destination it will reach if it keeps going in the direction we can see it going in now; it does not occur to us that its path is not a straight line but a curve, constantly changing direction" ${ }^{2}$ are quite alive today, perhaps even more alive than when they were written. After the traditional concept of respect for and knowledge of individual cultures, the need for interculturality has developed within societies, followed by multiculturality, while most recently the idea of transculturality is propagated, which Wolfgang Welsch defined as "a consequence of the inner differentiation and complexity of modern cultures" ${ }^{3}$. Containing interpenetration of cultures and hybridization, transculturality gives a new quality to globalization, which has important support in digital humanities. The digital humanities represent a state-of-the-art link between our highly digital contemporary world and humanities. Namely, this relatively newly formed discipline deals with the challenges that the permeation of these two engender. The relationship between digital humanities and transculturality is evident from the fact that it is precisely through digital environment that various cultures are mixed and merged and through which the understanding and interaction between different peoples and cultures are achieved on a global level. The current place of transculturality within digital humanities is extremely important, but its possible future role in the framework of digital humanities could be even greater. For the purpose of this paper, the idea of transculturality will be considered,

2 Wittgenstein, Ludwig. Culture and Value. Translated by Peter Winch. (Chicago: University Press, 1984): p.3e

3 Welsch, Wolfgang. Transculturality: The Puzzling Form of Culture Studies. In Spaces of Culture, City, Nation, World. Ed. Mike Featherstone and Scott Lash. (London: Sage, 1999): 194-213. 
as the one that is confirmed, decomposed and build upon in the light of digital humanities.

\subsection{The Blend of Transculturality and Globalization Concepts}

Since 1940 when it was defined up until this day, the term transculturality expanded its meaning, including rediscovering former cultural identities, mutual encounter of peoples and introduction to different cultures, liberation of certain nations from different social or dogmatic constraints, opposition to the idea of multiculturalism, which was often enclosed in the inherited cultural concepts, emphasizing culture as a central segment of our own national and state identity while developing skills for understanding and adapting to other cultures. Cultural fluidity and dynamics of cultural activities have their active stage in libraries, as ethically credible, historically libertarian and critically profiled educational, scientific, cultural, recreational institutions, socially and educationally responsible for new forms of cultural policy, the ratio of global communication and cultural heritage, as well as the maintenance of continuity of language and culture against social crisis.

Economic globalization, as the economic integration of the world, which takes place through trade, financial flows, exchange of technologies and information, and migrations of people, represents a superstructure of the base consisting of: the process of discerning social minimum acceptable to all, respect for diversity, ecumenical understanding of religious universalism, responsibility for family, society, national and cultural environment, as well as respect for human freedom and dignity, human rights and democracy, private property, material development of human society, social rights that stem from human rights, nature, its laws and unknowns, tolerance and non-violence. Globalization is seen as a benefit of modern times. Technological and communication advancements speak in favor of such a perception. The impact that it had on nature and the impoverishment of individuals and countries speak against the planetary perception of communion which is managed by multinational companies. Global information society depends on the intellectual, social, political, economic and historical specificities of national information infrastruc- 
tures, which, concludes Elaine Svenonius ${ }^{4}$, are conditioned by ideological example, linguistic conceptualization and sistematic generalization.

\subsubsection{Transculturality and Narcissism of Small Differences}

The respect for multiculturality, and even more for transculturality, is the achievement of democratic societies, whose stability and security is guaranteed by applying globally comparable and desirable measures directed towards attaining a good quality of life and protection of rights and cultural diversity of national minorities, i.e. through the protection of autonomy of each nation. Owing to the social order, which always involves certain social values, various cultural identities are conserved on the territory of the former Yugoslavia, including Serbia. With such valuable heritage, Serbia has followed the example of some countries by promoting multiculturalism through the recognition of the so-called cultural autonomy, which is defined and protected by law. The state has entrusted the national minorities themselves the right to manage certain areas that collectively make up the cultural identity of a nation: in the fields of culture, language, education, and thus enabled the preservation of national identities, cultures and languages of more than twenty peoples. In a post-conflict state, this was a very brave step, and certainly wisely established value concept that preserves ethnic and cultural heterogeneity of the country, but also promotes culture as a factor of connectivity and communion. This leads us towards the question of whether multiculturalism exists by itself in a situation where we have the presence of different cultures in one area or whether multiculturalism represents something more; this is in fact the most crucial theoretical question. The existence of cultural identities amongst which there is no interaction or mutual influences is not multiculturalism. This has led many theorists to conclude with resignation that the multiculturalism as a concept has failed in Europe. The reason for this lies in the feeling that we have a parallel existence of many cultures today, but not their mutual understanding and

4 Svenonius, Elaine. The Intellectual Foundation of Information Organization. (MIT Press, 2000) 
cultural exchange. In the Balkans, "the narcissism of small differences" ${ }^{5}$ was pronounced for decades in the field of culture. Narcissism of small differences refers to a phenomena of overemphasis differences (cultural, linguistic, religious) between two otherwise related nations, resulting from self-love. The concept of transculturality grows stronger precisely because of such consequences, as an attempt of rescuing democratic ideas, as a cultural anthropological concept, or as an improvement of forced multiculturalism and abstract interculturality ${ }^{6}$.

\subsubsection{Libraries as Facilitators of the Transculturality Process}

In the field of librarianship, transculturality becomes synonymous with the term "contact zone": "social spaces where cultures meet, clash, and grapple with each other, often in contexts of highly asymmetrical relations of power"7. By applying Bakhtin's theory of discourse in the novel, as monologue or dialogue, in which certain ritualization of roles is realized through linguistic genres, where he significantly prefers dialogue and polyphonic approach, Pratt compares Bakhtin's opinion with the opinion of Lev Vygotsky indicating that the sophisticated knowledge of language is leading towards sophisticated thinking. She sees the library as a contact zone, which recognizes the culture, language and identity of each individual user. "For authority figures, awareness of the contact zone brings increased consciousness of the way power is deployed and of the ethical demands of that power)." 8 Polyphony of users' voices is enabled and guided by their information literacy, which is often not at the satisfactory level; hence it is a task of libraries to develop this ability, skill and knowledge in order to ensure mutual contacts and cooperation. Mechanisms for bridging the language barriers, which are inherent to libraries, are al-

5 Baldwin, Peter. The Narcissism of Minor Differences: How America and Europe are alike. (Oxford University Press, 2009): 245

6 Gnisci, Armando, ed. La letteratura del mondo. (Roma: Sovera multimedia, 1993)

7 Pratt, Mary Louise adressed MLA Conference in 1991, according to Elmborg, J. (2006) "Libraries in the Contact Zone: on the Creation of the Educational Space", in Reference and User Services Quarterly, vol. 46, no 1, p. 56. Space", in Reference and User Services Quarterly, vol. 46, no 1, p. 59. 
lowing us to overcome natural cultural barriers. These are precisely the standards for cataloging and bibliographic processing, classification of human knowledge, methods of computational linguistics, thesaurus, questioning techniques of user needs through surveys, interviews. ${ }^{9}$

\section{Science, Culture, Education and digital humanites}

Science, culture and education, and consequently the institutions and individuals who are contributors to these areas are faced with new social values and movements, as well as with technological challenges. Digital humanities represent a contemporary response to these phenomena and build a reputation of the scientific discipline focused on technology rather than on cultural theories and the socio-political context. As Hayles explains, the transition to the term "digital humanities" is supposed to indicate that this area has rose up from not-so-prestigious position of ancillary services to a truly intellectual endeavour with its own professional procedures, rigorous standards and exciting theoretical research. ${ }^{10}$ The scientific discipline of digital humanities itself began as "humanities computing" or "humanistic computing", and during the first days, its role was very often understood as technical support for the work of "true" humanists who had the main saying within the projects.

\subsection{The Digital Humanities 2.0 Manifestos}

In their Digital Humanities Manifesto 2.0, Schnapp and Presner have explained that "the first wave of work within the digital humanities was (...) quantitative. It mobilized the possibilities of databases for searching and extracting data, automated corpus linguistics, laid HyperCards in critical sequences. The second wave is qualitative, interpretive, empirical, emotional, and generative in its character. It puts digital toolkits in the

9 Vraneš, A. (2013) Censorship and Intellectual Property with the Focus on Library Activities. In LibrAsia2013 - The Asian Conference on Literature and Librarianship, Osaka, Japan. ISSN 2186-2281. - Pp. 258-263.

10 Hayles, N. K. (2011) How We Think: Transforming Power and Digital Technologies, in Berry, D. M. (ed.) Understanding the Digital Humanities, London: Palgrave. 
service of fundamental methodological advantages of humanities: paying attention to the complexity, specificity of media, historical context, analytical depth, critiques and interpretation. The first wave of digital humanities in the late nineties and early 21st century was primarily focused on large digitization projects and establishment of technological infrastructure, while the current second wave of digital humanities, which can be called "digital humanities 2.0 " is deeply generative."11

As indicated in the book of Anne Burdick, Johanna Drucker, Peter Lunenfeld (et al.), digital humanities actually represent a collective singular, created as a result of the challenges and a link that exists between the notion digital and the notion humanities. ${ }^{12}$ Owing to the United Nations Organization for Education, Science and Culture, cultural heritage stands out as an essential factor of globalization and a pledge of international dialogue, while the use of new information and communication technologies, which preserve and promote it, should contribute to the affirmation and the achievement of EFA (Education for All) goals. Digitalization enables the preservation and promotion of the documentary and historical, cultural and scientific heritage, as well as contributes to the development of democracy of knowledge.

\subsubsection{The Role of Digital Humanities in Preserving the World's Cultural Heritage}

Electronic literature (e-lit), interactive fiction (IF), web artifacts, Twitter, social media, SMS novels are just some of the products on whose development and analysis the methodology of digital humanities can be applied. Easy access to digital materials, ease of research and sense of progress has created a parallel reality from the world of digital humanities. However, parallel doubts coexist within it: doubts concerning imprecision, uncertainty and transience of the presence of digital texts; doubts about the institutional soundness of scientific communication, in which we often refer to multiculturalism, multilingualism, interdisciplinarity, collaborativity. From the very inception of digital humanities, we are guided

11 Schnapp, J. and Presner, P. (2009) Digital Humanities Manifesto 2.0, retrieved 14/10/2010 from http://www.humanitiesblast.com/manifesto/Manifesto_V2.pdf

12 Anne Burdick, Johanna Drucker, Peter Lunenfeld (et al.). Dgital Humanities. (MIT Press, 2012). 
by one goal only: to protect, preserve and make available as many of the world's cultural heritage as possible in electronic form.

All achievements, both the current and the previous one, are subjected to harsh judgment, whether they are moderate or outrageous, heroic or stupid, private or public in nature. The line between critics and policy makers, scientists and entertainers became blurred. In Epstein's manifest "time is short, this is a genre in a hurry", the creator is warned that "if he is looking for linearity and logic or for an academic treatise, he is wrong, because the genre has only one logic: M's: mix :: match :: mash :: manifest, i.e.: don't whine, comment, engage, spread the word, join up; move on."13 Digital humanities are not a single field, but a series of convergent practices that explore the universe in which: a) printing is not the only normative medium any more through which knowledge is produced and/or distributed; printing is absorbed into new, multimedia configurations; b) digital tools, techniques and media are changing the production and dissemination of knowledge in the arts, humanities and social sciences.

Facing the challenges of education, each digital collection contributes to the spread of information literacy and general enlightenment, digital preservation, storage and use of documentary-historical, cultural and scientific heritage. Following this path, individual products will gradually abolish some of our smaller, or larger, but in any way freedoms to which we previously got used to. "Digital technologies are not", as Charlie Gere said, "just ordinary tools any more, but they are, for better or worse, progressively becoming participants in our increasingly participatory culture." ${ }^{14}$ Therefore, they are not limited by rules, regulations, codes, values and principles; but are instead guided in their research by creativity, critical attitude, dynamism, freedom of thought. Within digital humanities, the language becomes an increasingly important necessity, identification and divergence, and hence every research in the field of digital culture must begin and end with the questions of presence of conditionally smaller linguistic and cultural communities. By forming a digital collection of our humanities, we are returning a debt that we have towards their creators,

13 Epstein, M. The Digital Humanities Manifesto 2.0 t. from http://www.humanitiesblast. com/manifesto/Manifesto_V2.pdf

14 Gere, Charlie. Digital Culture.(University of Chicago Press, 2009). 
previous generations, and we are obligating the following generations to continue to preserve our culturalogical, religious and national identity, as well as promote transculturality.

\subsubsection{Digital Humanities as Museums, Libraries, Archives, Galleries without Walls and Mix of Media}

Digital Humanities involve: museums, libraries, archives, galleries without walls; democratization of knowledge and culture; the abolition of boundaries between the natural and social sciences; intellectual creativity; mix of media; sometimes even digital anarchy and the same appreciation for the creative copy as for the original. Generative Humanities, as its highest form, include: improvement of the bigger picture of the expert knowledge; cooperation and creativity; transversal, transdisciplinary, innovative thinking; teamwork; a process, not a product; popularization of knowledge outside the university.

According to the existing manifestos, which are not few in number, and considering that both institutions and individuals are in need of canonization, in this particular case unreached, all this is achieved through: the expansion of quality, scope and influence of knowledge in the humanities and the process of engaging in the design and developmental processes that lead towards richer, multi-directional models, genres, academic communication and practice. Traditional humanities are "Balkanized" by means of language, nation, methodology and media. Digital humanities represent convergence not only between humanistic disciplines, but also between arts, sciences and technologies, whose main characteristics refer to: curiosity, openness, permeation of research, application of new methodologies, freedom in terms of using copyright, creativity, courage, vision, freedom to dispose with contents, pedagogical resourcefulness.

\section{CONCLUding remarks}

Presentation of historical, cultural and national achievements, in order to emphasize national identity on the one hand and a friendly inten- 
tion, on the other, attributes an important social role to books and libraries. Libraries, museums, archives, theaters, cinemas - are active agents in terms of transcultural and international communication, "permanent and reliable ambassadors of well kept cultural values and heritage, which in its digital form achieve the desired unity of action, time and space since forever" 15 . Digital Humanities preserve, in widely accessible electronic form, cultural, religious and national identity of the collective or individuals and enables mutual understanding between nations. New digital literacy and digital humanities, with constant reliance in social, literary and art history and aesthetics, is the new creative strategy of contemporary transculturality.

\section{References}

Adam, A. (1998). Artificial knowing: Gender and the thinking machine. London: Routledge.

Baker, N. (1996) The Size of Thoughts: Essays and Other Lumber, New York: Random House.

Baker, N. (2001) Double Fold: Libraries and the Assault on Paper, New York: Random House.

Berry, D. M. (2011) The Philosophy of Software: Code and Mediation in the Digital Age, London: Palgrave Macmillan.

Clinamen (2011) The Procedural Rhetorics of the Obama Campaign, retrieved 15/1/2011 from http://clinamen.jamesjbrownjr.net/2011/01/15/the-procedural-rhetoricsof-the-obama-campaign/

Elmborg, J. (2006) "Libraries in the Contact Zone: on the Creation of the Educational Space", in Reference and User Services Quarterly, vol. 46, no 1, p. 56-64

"Feminizing the Textual Body: Women and their Literary Annuals in Nineteenth-Century Britain." Papers of the Bibliographical Society of America 99.4 (Dec. 2005): 573-622.

Flanders, J. (2009) The Productive Unease of 21st-century Digital Scholarship, Digital Humanities Quarterly, Summer 2009, Volume 3 Number 3, retrieved 10/10/2010 from http://digitalhumanities.org/dhq/vol/3/3/000055/000055.html

Fuller, M. (2008) Software Studies $\backslash A$ Lexicon, London: MIT Press.

Fuller, S. (2010) Humanity: The Always Already - or Never to be - Object of the Social Sciences?, in Bouwel, J. W. (ed.) The Social Sciences and Democracy, London: Palgrave.

Haraway, D. "A Cyborg Manifesto Science, Technology, and Socialist-Feminism in the Late Twentieth Century," in Simians, Cyborgs and Women: The Reinvention of Nature (New York; Routledge, 1991), pp.149-181.

15 Vraneš, Aleksandra.World Heritage: From the Manuscript to the Digital Form. In European Review. Volume 23, Issue 3, July 2015, pp. 354-360 
Hayles, N. K. (2011) How We Think: Transforming Power and Digital Technologies, in Berry, D. M. (ed.) Understanding the Digital Humanities, London: Palgrave.

JAH (2008) Interchange: The Promise of Digital History, The Journal of American History, retrieved 12/12/2010 from http://www.journalofamericanhistory.org/ issues/952/interchange/index.html

Lakatos, I. (1980) Methodology of Scientific Research Programmes, Cambridge: Cambridge University Press.

Liu. A. (2003) The Humanities: A Technical Profession, retrieved 15/12/2010 from http:// www.english.ucsb.edu/faculty/ayliu/research/talks/2003mla/liu_talk.pdf

Liu, A. (2011) Where is Cultural Criticism in the Digital Humanities, retrieved 15/1/2011 from http://liu.english.ucsb.edu/where-is-cultural-criticism-in-the-digital-humanities/

Manovich, L. (2008) Software Takes Commons, retrieved 1/12/2010 from http://lab. softwarestudies.com/2008/11/softbook.html

McCarty, W. (2009) Attending from and to the machine, retrieved 18/09/2010 from http://staff.cch.kcl.ac.uk/ wmccarty/essays/McCarty,\%20Inaugural.pdf

Montfort, Nick. (2004) Continuous Paper: The Early Materiality and Workings of Electronic Literature, retrieved 16/1/2011 from http://nickm.com/writing/ essays/continuous_paper_mla.html

Montfort, N. and Bogost, I. (2009) Racing the Beam: The Atari Video Computer System, London: MIT Press.

Moretti, F. (2000) Conjectures on World Literature, retrieved 20/10/2010 from http:// www.newleftreview.org/A2094

Moretti, F. (2007) Graphs, Maps, Trees: Abstract Models for a Literary History, London, Verso.

Ramsay, S. (2011) On Building, retrieved 15/1/11 from http://lenz.unl.edu/wordpress/?p=340

Sample, M. (2011) Criminal Code: The Procedural Logic of Crime in Videogames, retrieved 15/1/2011 from http://www.samplereality.com/2011/01/14/criminal-code-theprocedural-logic-of-crime-in-videogames/

Schnapp, J. and Presner, P. (2009) Digital Humanities Manifesto 2.0, retrieved 14/10/2010 from http://www.humanitiesblast.com/manifesto/Manifesto_V2.pdf

Schreibman, S., Siemans, R., and Unsworth, J. (2008) A Companion to Digital Humanities, London: Wiley-Blackwell.

"TechnoRomanticism: Creating Digital Editions in an Undergraduate Classroom." Journal of Victorian Culture 16:1 (2011 April): 107-112.

Vraneš, A. Marković, Lj. Achleitner, H. Dimchev, A. (2005) The Information Society : barriers to the free access to information. In European Curriculum Reflections on Library and Information Science Education / edited by Leif Kajberg and Leif Lorring. Copenhagen : The Royal School of Library and Information Science. ISBN 87-7415-292-0. - p. 105-125.

Vraneš, A. Marković, Lj. (2013) Information Literacy in the Focus of Ethics, in ICIL.

Vraneš, A. (2013) Censorship and Intellectual Property with the Focus on Library Activities. In LibrAsia2013 - The Asian Conference on Literature and Librarianship, Osaka, Japan. - ISSN 2186-2281. - Pp. 258-263 